\title{
Family Tourist - is Different Motive, Different Choice of Tourist Activity?
}

\author{
Rahmat Ingkadijaya
}

Sekolah Tinggi Pariwisata Trisakti, Jakarta

Corresponding author: rahmatingka@gmail.com

\begin{abstract}
ARTICLE INFO
ABSTRACT

Received

22 August 2018

Accepted

12 September 2018

Available online

20 September 2018

Currently, many families travelling to various tourist destinations. This phenomenon is interesting to be investigated. Existing research results can be utilized by stakeholders to develop their own policies and strategies. However, at this time not much study exists in family travel. This study examines family's travel motivations, family's activities in destination, and the differences of family's activity choice across categories of travel motivations. Survey method has been employed in this study. The sample was obtained from a residence in Bogor City, West Java and consisted of 300 families chosen by convenience sampling technique. Data were analyzed using descriptive analysis and hypothesis test using chi-square. The findings indicated that there were two dominant family's travel motivations, personal escape and interpersonal seeking. The family chose natural, cultural, and special tourist activities. Family's activity choice across categories of travel motivations was the same except rafting. It was most preferred by families who had personal escape motivation.
\end{abstract}

Keywords : Family travel, travel motivations, tourist activities

\section{INTRODUCTION}

\section{Background}

There is a new trend in Indonesian society, namely recreational activities or holiday with family to various tourism destinations. For example, Bandung as one of the favourite tourist destinations for the family, every holiday is always crowded with family tourists, so the traffic jammed extraordinary. The hotels are so crowded with the family tourist that their capacity is exceeded. Similarly, recreational spots, shopping and culinary centres are full of families (Ingkadijaya et al., 2016a).

Statistical data shows that the domestic tourists who visited Bandung increased by about 27.3 percent, from 2.928 million people in 2009 to 3.726 million people in 2013 (BPS Bandung, 2014). Research by Goeltom and Mulyawan (2007) shows, that 60 percent of the total tourists who visit Bandung

http://ojs.unud.ac.id/index.php/eot is a family group. Of course Bandung is not the only city packed with family tourists while on vacation. Similar trends also occur in other cities in Indonesia, such as Yogyakarta and Bogor.

There are various reasons contributing to the increased volume of family travel. Firstly, the increase of family holiday travel is in accordance with the enhanced income of working parents (husband and wife). They use the holidays as a means to strengthen family bonds. This phenomenon shows that the working and married families are aware of their shortcomings in establishing communication and relationships with children in everyday life. They try to improve relationships between family members by using free time to mingle in the form of recreation or holiday travel (Nickerson and Jurowski, 2001).

Another reason is due to rapid social change in Indonesian society (Damanik, 2014). The changes can be seen, among 
others, the smaller number of children, the role of extended family is decreasing, the increase in household income, the large proportion of mothers entering the labour market accompanied by high demands for professional employment.

Urbanization has also contributed to the increased volume of family travel. The rate of urbanization in Java, for example, in the period 2000-2010 recorded about 3.1 to 3.6 percent per year, resulting in increased urban density and implications for space constraints for relaxation. The rigorous rhythm of work (school, office work, etc.) also requires families to make the most of their free time. In short, the community is enjoying "demographic and economic bonuses" that spur outward movement of residence for tourism activities (Damanik, 2014).

The benefits of recreation and tourism for family institutions have been widely studied in the research. Primarily, a family vacation that is manifested in the form of a tour to a destination can strengthen the relationship between family members (Brimacombe, as cited in Hazel, 2005). Other studies have also concluded outdoor recreation, including travel, helps maintain and improve family cohesion (Ingkadijaya et al., 2016b). The further positive effect is that with increased family relationships the possibility of children falling into a variety of juvenile delinquency can be reduced (Stephenson, as cited in Hazel, 2005).

Given the importance of tourism activities for the existence and cohesiveness of families and communities, stakeholders (government and tourism industry actors) should pay serious attention. The government policies should address the urgency of providing adequate transportation facilities and infrastructure. Similarly, tourism industry actors should facilitate families in fulfilling their needs during travel, because the family is a huge market for them.

To be able to accommodate the needs of family tourists effectively, it is necessary to have a first understanding of the motives behind their travel. From this understanding, it will reveal what activities are carried out by families in tourist destinations. Furthermore, it is also necessary to study the relevance of the selection of tourism activities with the motifs that lie behind. Information about the motives and activities of this family tour will greatly

http://ojs.unud.ac.id/index.php/eot help the stakeholders in the preparation of plans and strategies to meet the needs of family tourists.

In addition, research on family tourists is not as much as research on individual tourists. Previous research on individual tourists has been carried out by previous researchers, such as Suardana, Bendesa and Antara (2014); Utama, Putra and Suradnya (2014); Manulang, Bendesa and Putra (2015); Sudiarta (2015); Amelia and Palupi (2016). This study intends to add to the repertoire of research on family tourists.

\section{Research Objectives}

This study deals with these matters above. More specifically, it aims to analyze (1) the motives behind family travel, (2) tourism activities conducted by the family, and (3) the difference in the selection of tourism activities based on the underlying motives.

\section{LITERATURE REVIEW}

\section{Tourist Motives}

Motives are internal factors that make a person feel something, direct, and integrate his behaviour (Murray, as cited in Snepenger et al., 2006). Motives are not able to be directly observed, but are inferred from one's behaviour or assumed to exist to explain the behaviour. Research on travel motives tends to focus on the fundamental questions about why a person travels. The motive of travelling is defined as "a need, reason, or satisfaction that stimulates involvement in a leisure activity" (Crandal, as cited in Chen and Pang, 2012).

There are two factors that are claimed to be very influential in the motive of travel, which is the push factor and pull factor (Uysal \& Jurowski, as cited in Bowen and Clarke, 2009) are also often called intrinsic motives (Iwasaki \& Mannel, as cited in Chen and Pang, 2012) and extrinsic motives (Recours, Souville and Griffet, 2004; Hayenga \& Corpus, as cited in Chen and Pang, 2012). The push factor is the factor that makes one want to travel, while the pull factor is the factor that influences where one is going (Dann cites Ross, 1998). The push factor is intangible that the intrinsic drive of the individual travels, such as the drive to escape, rest and relaxation, adventure, health, or prestige. The pull factor 
is related to the attractiveness of tangible tourist destination attributes (Kozak, as cited in Bowen and Clarke, 2009).

Hsu, Cai and Li (2010) tries to map the constellation of tourist motives to travel based on the results of previous research. From a number of findings of experts, they came to the conclusion that the motive of travel is very diverse and does not apply singularly to everyone. In individual figures, for example, a person is stimulated by a situation that is expected to benefit his actions. This means that the motive of travel is born from one's choice of action which is expected to provide benefits (Hsu, Cai and $\mathrm{Li}, 2010$ ). However, the cultural context is an important consideration (Walker, Deng and Dieser, 2005). That is, the motive of action (travel) is always associated with the norms of society. In an individualist society, personal considerations are more prominent than collective rationality (Srite \& Karahanna, as cited in Chen and Pang, 2012).

Crompton found nine travel motivations: (1) escape from the perceived normal environment, (2) recognition and selfassessment, (3) relaxation, (4) dignity, (5) regression, (6) familial development, 7) ease of social interaction, (8) novelty, and (9) education (Ross, 1998). The first seven motivations are grouped into psychological motivations or push factors while the latter two motivations are grouped into the cultural motivation or pull factors. The motive for strengthening family relationships is important to be explored as it relates to cultural differences between communities.

The classification of motivation of the pusher and the puller can not be separated from one another. Tourists can strike a balance between the escape motivation of the daily routine with the motivation of seeking for something new or different (Bowen and Clarke, 2009). Therefore, Iso-Ahola proposes a seeking and escaping approach. This approach assumes an individual can have both motives simultaneously. In addition, both motives have personal (psychological) and interpersonal (social) components so that motivation has four dimensions: personal escape, personal seeking, interpersonal escape, and Interpersonal seeking (Bowen and Clarke, 2009).

The motive of personal escape is the drive from within a person to get out of the

http://ojs.unud.ac.id/index.php/eot normal environment, get change from everyday life, and overcome bad mood. The motive of personal-seeking is an inner impulse to share experiences with others, feel good about themselves, and experience new things. The motive of interpersonal escape is an inner impulse to avoid disruptive people, break out of a stressful social environment, and avoid interaction with others. The interpersonal seeking motive is an inner impulse to be with other interested people, to bring friends/family closer together, and to meet new people (Snepenger et al., 2006).

Although theoretically tourists can have several motives simultaneously, but this study focuses on the most dominant travel motif of every family.

\section{Tourist Activities}

Another concept included in this research is the concept of tourist activity. Tourist activity is the activity of tourists in tourist destinations. The type of activity that tourists do is very dependent on the facilities and tourist attractions available in tourist destinations. Facilities and tourist attractions between tourist destinations are not the same, there is always a difference. Inskeep (1991) classifies tourist activities based on tourist attractions into three groups, namely natural tourist activities, cultural tourist activities, and special tourist activities.

In the beginning, nature-based tourism is used as a kind of tourism, alternative to mass tourism (Lindberg, cited in Tangeland and Aas, 2011). Other names of nature-based tourism, among them are sustainable tourism, green tourism, responsible tourism, alternative tourism, and adventure tourism. However, in further developing nature-based tourism includes commercial outdoor recreational based activities, such as trekking, hiking, climbing, and rafting (Tangeland and Aas, 2011).

In this study, natural tourist activity is the activity of tourists in the area of nature tourism. These activities include sightseeing, outdoor play, mountain climbing, camping, white water rafting, swimming on the beach, snorkelling, scuba diving, fishing, hot springs bathing, cave exploration, visiting zoos or safari parks, visiting Botanical gardens, and visited the farm area.

Cultural tourist activities are tourist 
activities that focus on all products or cultural attractions. These activities include visiting cultural/historical/archaeological sites, viewing local cultures such as customs and ceremonies, watching art performances such as dance and music, seeing interesting economic activities such as tea processing, looking at the architecture of a house/church building/mosque, visiting museums, and watching cultural festivals (Damanik, 2013).

Special tourist activities are the activities of tourists to enjoy/take advantage of tourist attractions that are deliberately created to meet the recreational needs of local residents and tourists (Inskeep, 1991). These activities include visiting a theme park, shopping at shopping centres, watching sports competitions, and culinary tours.

Tourist activity can be influenced by several things, among which are it can be affected by time (Birenboim et al., 2013) and place (Shoval et al., 2011). This study examined the relationship between the tourist motive and their choice of activity.

To find out whether the tourist activity is really distinguishable based on the tourist motive, then this study proposed three hypotheses, namely: first, there are differences in the choice of natural tourist activities based on the travel motives; Secondly, there are differences in the choice of cultural tourist activities based on the travel motives; And thirdly, there are differences in the choice of special tourist activities based on the travel motives.

\section{RESEARCH METHOD}

This study chose the location in Bogor City. Geographically Bogor City is very close to DKI Jakarta, is approximately $56 \mathrm{~km}$. With this strategic location, this city becomes one of the city that gets the population of the Jakarta Capital City. This strategic location also has made the city experiencing economic growth and services, and became the centre of national activities for industry, trade, transportation, communications, and tourism. Therefore, many residents from other areas are interested in moving to this city. This led to the growth of new housing complexes inhabited by a diverse population of socioeconomic and cultural backgrounds.

In addition, around Bogor City also there are many objects and tourist attractions,

http://ojs.unud.ac.id/index.php/eot which makes the people of Bogor City become accustomed to doing recreational activities and tourism. The characteristics of the population make the research on the behaviour of tourists relevant conducted in Bogor City, especially among residents who live in residential complexes that are now rampant in the city.

The survey approach was used in this study because it tried to generalize the population by using samples and collecting information from the respondents by using questionnaires as the main tool. This means surveys are meant to identify specific groups and gather information about them to get an idea of the overall characteristics of the group (De Leeuw, Hox and Dillman, 2012). Therefore, all settlers in the housing complex in Bogor City used as a population, while the sample is a household that resides in the housing complex. The head of the household is deliberately selected as an analytical unit because it is considered capable of providing complete information about the issues studied. Determination of population and sample is based on the following two considerations. First, families living in residential complexes are generally more heterogeneous than those living in the township. The heterogeneity of the background is assumed to lead to differences in travel behaviour between them. Second, the head of the family who lives in the housing complex is also generally active workers. They are considered capable of travelling with all members of his family.

Convenience sampling technique, the sample is taken based on the availability of elements and ease of obtaining it (Sugiarto, et al., 2001) is deliberately used due to technical constraints in the field. The sample size is set at 300 units. Data were collected by distributing questionnaires in 42 residential complexes in five sub-districts from six subdistricts in Bogor city, Bogor Selatan subdistrict, Bogor Timur sub-district, Bogor Barat sub-district, Bogor Utara sub-district and Tanah Sareal sub-district.

The collected data were then analyzed using descriptive statistics, while the interrelations between variables were used cross tabulation and chi-square. All data collected is processed using statistical data processing software SPSS + (Statistical Product and Service Solutions previously named Statistical Package for the Social Sciences). 


\section{RESULTS AND DISCUSSION}

\section{Results}

\section{Respondent Profile}

Most fathers (husbands), in this study, were between $45-54$ years old (43.3\%). This age group can be regarded as a group of people who have matured psychologically and well-established economically. Therefore, fathers in this age group can be assumed to understand the importance of establishing and maintaining intimacy among their family members. They try to make various efforts to achieve it. Because it is economically established, then they do not face cost constraints, although to achieve these goals require financing is not small, such as traveling with family out of town.

Most mothers (wives) are aged 35-44 years $(40.0 \%)$. It also shows that the mother figure in the respondent's family is at a psychological maturity stage just like the father and if the mother works is in the stage toward establishing economically. So, it can be concluded that married couples in this study are parents who have matured psychologically and well-established economically, so it can be assumed able to make a family tour and consider it important to establish and maintain relationships between family members.

Table 1. Age of Husbands, Wives, and

\begin{tabular}{crr|cr}
\multicolumn{5}{c}{ Children $(\%)$} \\
\hline $\begin{array}{c}\text { Age } \\
\text { (year) }\end{array}$ & Husband & Wive & $\begin{array}{c}\text { Age } \\
\text { (year) }\end{array}$ & Children \\
\hline $25-34$ & 9,0 & 18,0 & $<5$ & 5,3 \\
$35-44$ & 29,3 & 40,0 & $05-14$ & 28,0 \\
$45-54$ & 43,3 & 35,3 & $15-24$ & 47,3 \\
$\geq 55$ & 18,1 & 6,7 & $>24$ & 19,4 \\
\hline Total & 100,0 & 100,0 & & 100,0 \\
& $\mathrm{~N}=300$ & $\mathrm{~N}=30$ & & $\mathrm{~N}=300$
\end{tabular}

Age of children in the family of respondents is $15-24$ years $(47,3 \%)$, that is stage of adolescent age. At this stage of age, children are usually able to travel independently without accompanying parents, but still feel happy to travel with his family. However, the families of respondents who have children aged 5-14 years are also quite a lot $(28 \%)$. Groups of this age children still need a parent or adult mentoring in travel.
Therefore, this age group of children is most often found in tourist objects with their families.

In this study, most families of respondents had family members of about 3-4 people (59.7\%), and most families had children about 1-2 people (69.7\%). Among the families surveyed, there were families with members other than fathers, mothers and children (other relatives), but very few (14.7\%). The most common form of family is the nuclear family $(85.3 \%)$. The nuclear family is a family of fathers, mothers, and children, with no other family members other than children. So, the majority of respondents in this study is a nuclear family that has 1-2 children.

In terms of family tourism, because the number of family members is small and has relatively strong emotional ties, the nuclear family finds it easier to find out where to travel and what to do. In addition, the small number of family members can also further ease the financing of travel.

Table 2. Number of Family Members

\begin{tabular}{cr}
\hline Number of Family Members & $\%$ \\
\hline $3-4$ & 59,7 \\
$5-6$ & 38,0 \\
$\geq 7$ & 2,3 \\
\hline Total & 100,0 \\
& $\mathrm{~N}=300$ \\
\hline
\end{tabular}

\section{Travelling Motives Based on Family Characteristics}

The data show that the personal escape motive is the most dominant motive $(46.3 \%)$ for families to travel. The second largest motive $(36.0 \%)$ is interpersonal seeking motive. In addition to the above main motive, interpersonal escape is still included in this study, although the numbers are small (9.0\%). Interesting also note, that the tour based on personal seeking motive is almost irrelevant in the lives of most respondents. The percentage of those who voted for this answer was the smallest $(8.7 \%)$.

Based on the existence of its members, families can be grouped into two, namely the nuclear family and extended family. The nuclear family is a family of husbands (fathers), wives (mothers), and children, while the extended family is a family of members 
like the nuclear family plus other family members. The data show that the personal escape motive is more prevalent in the nuclear family $(46.9 \%)$ than in the extended family $(43.2 \%)$. In contrast, interpersonal seeking, interpersonal escape, and personal seeking are more common in extended families $(38.6 \%$, $9.1 \%$, and $9.1 \%$ ) than in the nuclear family $(35.5 \%, 9.0 \%$, and $8.6 \%)$.

Table 3. Travelling Motive by Family Type (\%)

\begin{tabular}{lrr}
\hline \multirow{2}{*}{ Motives } & \multicolumn{2}{c}{ Family Type } \\
\cline { 2 - 3 } & $\begin{array}{c}\text { Nuclear } \\
\text { Family }\end{array}$ & $\begin{array}{c}\text { Extended } \\
\text { Family }\end{array}$ \\
\hline Personal escape & 46.9 & 43.2 \\
Personal seeking & 8.6 & 9.1 \\
$\begin{array}{l}\text { Interpersonal } \\
\text { escape }\end{array}$ & 9.0 & 9.1 \\
$\begin{array}{l}\text { Interpersonal } \\
\text { seeking }\end{array}$ & 35.5 & 38.6 \\
\hline Total & 100.0 & 100.0 \\
& $\mathrm{~N}=256$ & $\mathrm{~N}=44$ \\
\hline
\end{tabular}

The family life cycle is the stages that the family goes through in line with the increasing age of family members. The family stages in this study used the age of the first child (oldest), so that the four family stages were obtained, namely (1) full family stage with children aged less than 5 years, (2) full family stage with children aged 5-14 years, (3) full family stage with children aged 15-24 years, and (4) full family stage with children aged over 24 years.

The data indicate that personal escape motive mostly exists in the full family stage with children aged 5-14 years (56.0\%). Interpersonal seeking motives are most prevalent at the full families stage with children over 24 years old $(48.3 \%)$. The personal seeking motive is most prevalent on the full family stage with children younger than 5 years $(18.8 \%)$. Interpersonal escape motives are most prevalent at the full family stage with children aged $15-24$ years (11.3\%).
Table 4. Travelling Motive According to Family Life Cycle (\%)

\begin{tabular}{|c|c|c|c|c|}
\hline Motives & $\begin{array}{c}<5 \\
\text { years }\end{array}$ & $\begin{array}{l}5-14 \\
\text { years }\end{array}$ & $\begin{array}{c}15-24 \\
\text { years }\end{array}$ & $\begin{array}{l}>24 \\
\text { years }\end{array}$ \\
\hline $\begin{array}{l}\text { Personal } \\
\text { escape }\end{array}$ & 43.8 & 56.0 & 43.0 & 41.4 \\
\hline $\begin{array}{l}\text { Personal } \\
\text { seeking } \\
\text { Interpersona }\end{array}$ & 18.8 & 8.3 & 9.9 & 3.4 \\
\hline $\begin{array}{l}\text { l escape } \\
\text { Interpersona }\end{array}$ & 6.3 & 7.1 & 11.3 & 6.9 \\
\hline 1 seeking & 31.3 & 28.6 & 35.9 & 48.3 \\
\hline Total & $\begin{array}{l}100.0 \\
N=16\end{array}$ & $\begin{array}{l}100.0 \\
N=84\end{array}$ & $\begin{array}{r}100.0 \\
\mathrm{~N}=142\end{array}$ & $\begin{array}{r}100.0 \\
\mathrm{~N}=58\end{array}$ \\
\hline
\end{tabular}

Based on marital status, the data indicate that the personal escape motive is more prevalent in families where one or both spouses are unemployed $(47.6 \%)$ than the working married family (45.9\%). Similarly, the interpersonal seeking motive is also more prevalent in families where one or both spouses are unemployed (40.2\%) than the working marital family (34.4\%).

In contrast, the interpersonal escape motive is more prevalent in working-spousal families $(11.0 \%)$ than families with one or both spouses not working (3.7\%). Similarly, personal seeking motives are more prevalent in working-spousal families $(8.7 \%)$ than in families of one/both unemployed (8.5\%).

Table 5. Travelling Motive According to Status of Work Husband and Wife $(\%)$

\begin{tabular}{lcc}
\hline \multirow{2}{*}{ Motives } & \multicolumn{2}{c}{ Status of Spouse } \\
\cline { 2 - 3 } & $\begin{array}{c}\text { One / Both } \\
\text { Husbands Wife Not } \\
\text { Working }\end{array}$ & $\begin{array}{c}\text { Husband and Wife } \\
\text { Working }\end{array}$ \\
\hline $\begin{array}{l}\text { Personal } \\
\text { escape }\end{array}$ & 47.6 & 45.9 \\
$\begin{array}{l}\text { Personal } \\
\text { seeking }\end{array}$ & 8.5 & 8.7 \\
$\begin{array}{l}\text { Interpersonal } \\
\text { escape }\end{array}$ & 3.7 & 11.0 \\
$\begin{array}{l}\text { Interpersonal } \\
\text { seeking }\end{array}$ & 40.2 & 34.4 \\
\hline Total & 100.0 & 100.0 \\
& $\mathrm{~N}=82$ & $\mathrm{~N}=218$ \\
\hline
\end{tabular}

\section{Choice of Activities and their Relation to Tourist Motives}

The results showed that the family did all types of tourist activities, namely the activities of nature, cultural, and special. Of the three types of tourism activities, selected by more than $50 \%$ of respondents are culinary 
$(65.3 \%)$, shopping (64.0\%), sightseeing $(62.7 \%)$, and visiting the theme park $(53.7 \%)$.

Nature tourism - such as: sightseeing, swimming on the beach, playing outdoors, visiting zoos / safari parks, visiting agro, hot springs bathing, fishing, diving, rafting, mountain climbing, camping and exploring caves, mostly chosen by the family who has personal escape motives. There is only one natural tourism activity that is most preferred by the family who has interpersonal seeking, they visit the botanical garden.

The data also reveal that cultural tourism activities: seeing the architecture of buildings, visiting historical relics, watching traditional ceremonies, visiting museums, seeing economic activities, and watching cultural festivals are the most widely chosen by family with personal escape motive. Watching art shows most preferred by interpersonal-seeking family.

In addition to the activities of nature and culture, the data also show that most of the special tourist activities (shopping tour, culinary tour, visiting theme park) are most preferred by family with personal escape motives, while watching sports competitions are chosen both by family with personal escape motives and family with interpersonal seeking motives.

Table 6. Choice of Activities Based on Travel Motives (\%)

\begin{tabular}{|c|c|c|c|c|c|}
\hline \multirow[b]{2}{*}{ No. } & \multirow[b]{2}{*}{$\begin{array}{l}\text { Tourist } \\
\text { Activity }\end{array}$} & \multicolumn{4}{|c|}{ Motives } \\
\hline & & $\begin{array}{c}\begin{array}{c}\text { Personal } \\
\text { escape }\end{array} \\
\end{array}$ & $\begin{array}{c}\begin{array}{c}\text { Personal } \\
\text { seeking }\end{array} \\
\end{array}$ & $\begin{array}{c}\text { Interpersonal } \\
\text { escape }\end{array}$ & $\begin{array}{c}\text { Interpersonal } \\
\text { seeking }\end{array}$ \\
\hline \multicolumn{6}{|c|}{ Nature tourism } \\
\hline 1. & sightseeing & 47.9 & 9.6 & 5.9 & 36.7 \\
\hline 2. & $\begin{array}{l}\text { swimming } \\
\text { on the beach }\end{array}$ & 45.3 & 8.0 & 8.0 & 38.7 \\
\hline 3. & $\begin{array}{l}\text { playing } \\
\text { outdoors }\end{array}$ & 48.1 & 10.5 & 8.3 & 33.1 \\
\hline 4. & $\begin{array}{l}\text { visiting zoos } \\
\text { / safari parks }\end{array}$ & 45.5 & 11.6 & 8.0 & 34.8 \\
\hline 5. & $\begin{array}{l}\text { visit the } \\
\text { botanical } \\
\text { garden }\end{array}$ & 40.7 & 9.3 & 8.1 & 41.9 \\
\hline 6. & visiting agro & 39.7 & 6.9 & 17.2 & 36.2 \\
\hline 7. & $\begin{array}{l}\text { hot springs } \\
\text { bathing }\end{array}$ & 42.0 & 14.0 & 4.0 & 40.0 \\
\hline 8. & Fishing & 45.5 & 18.2 & 3.0 & 33.3 \\
\hline 9. & $\begin{array}{l}\text { scuba diving } \\
\text { and } \\
\text { snorkelling }\end{array}$ & 46.4 & 10.7 & 3.6 & 39.3 \\
\hline 10. & Rafting & 55.6 & 27.8 & 0.0 & 16.7 \\
\hline 11. & $\begin{array}{l}\text { mountain } \\
\text { climbing }\end{array}$ & 57.1 & 7.1 & 7.1 & 28.6 \\
\hline 12. & Camping & 69.2 & 7.7 & 0.0 & 23.1 \\
\hline 13. & $\begin{array}{l}\text { exploring } \\
\text { caves }\end{array}$ & 62.5 & 0.0 & 0.0 & 37.5 \\
\hline \multicolumn{6}{|c|}{ Culture tourism } \\
\hline 14. & $\begin{array}{l}\text { seeing the } \\
\text { architecture } \\
\text { of buildings }\end{array}$ & 48.9 & 13.3 & 2.2 & 35.6 \\
\hline 15. & $\begin{array}{l}\text { visiting } \\
\text { historical } \\
\text { relics }\end{array}$ & 46.5 & 14.0 & 9.3 & 30.2 \\
\hline 16. & $\begin{array}{l}\text { watching art } \\
\text { shows }\end{array}$ & 27.0 & 13.5 & 16.2 & 43.2 \\
\hline 17. & watching & 42.9 & 14.3 & 5.7 & 37.1 \\
\hline
\end{tabular}

http://ojs.unud.ac.id/index.php/eot

\begin{tabular}{|c|c|c|c|c|c|}
\hline 18. & $\begin{array}{l}\text { traditional } \\
\text { ceremonies } \\
\text { visiting } \\
\text { museums }\end{array}$ & 48.4 & 9.7 & 6.5 & 35.5 \\
\hline 19. & $\begin{array}{l}\text { seeing } \\
\text { economic }\end{array}$ & 47.1 & 11.8 & 11.8 & 29.4 \\
\hline 20. & $\begin{array}{l}\text { activities } \\
\text { watching } \\
\text { cultural } \\
\text { festivals }\end{array}$ & 52.6 & 15.8 & 5.3 & 26.3 \\
\hline \multicolumn{6}{|c|}{ Special tourism } \\
\hline 21. & $\begin{array}{l}\text { shopping } \\
\text { tour }\end{array}$ & 46.9 & 8.3 & 9.4 & 35.4 \\
\hline 22. & culinary tour & 44.4 & 9.2 & 10.2 & 36.2 \\
\hline 23. & $\begin{array}{l}\text { visiting } \\
\text { theme park }\end{array}$ & 47.2 & 8.1 & 8.1 & 36.6 \\
\hline 24. & $\begin{array}{l}\text { weme park } \\
\text { watching } \\
\text { sports } \\
\text { competitions }\end{array}$ & 42.3 & 11.5 & 3.8 & 42.3 \\
\hline
\end{tabular}

To know the difference of tourism activity choice based on tourist motif, then tested the hypothesis of chi-square with significance level $5 \%(0.05)$. The results of hypothesis testing can be seen in the table below. It appears that the significance value of all natural tourism activities is greater than 0.05 and only rafting alone whose significance value is less than 0.05 . This indicates that the activities of nature tourism are chosen not only by personal escape family, but also by personal seeking, interpersonal escape, and interpersonal seeking. The number of personal escape families who choose this activity does not mean they are more suitable / in accordance with the activities compared with other patterned family. This nature tourism activity is suitable for all family types. There is only one natural tourism activity that is really suitable for families with personal escape motif, i.e. white water rafting (sig: 0.007).

Hypothesis test results of cultural tourism activities showed that all cultural activity gained significant value greater than 0.05 . This means that there is no difference in the selection of cultural tourism activities among families with personal escape, personal seeking, interpersonal escape, and interpersonal seeking. The same is true of special tourism activities, all the special tourist activities have significant value greater than 0.05 . 
Table7. Hypothesis Test Results on Differences Choice of Tourism Activities Based on Travel Motives

\begin{tabular}{|c|c|c|c|c|}
\hline No. & Tourist Activities & $\chi^{2}$ & Sig & Result \\
\hline \multirow{3}{*}{$\begin{array}{l}1 . \\
2 .\end{array}$} & Nature tourism & & & \multirow{3}{*}{$\begin{array}{l}\mathrm{H}_{0} \text { accepted } \\
\mathrm{H}_{0} \text { accepted }\end{array}$} \\
\hline & Sightseeing & 6.353 & 0.096 & \\
\hline & $\begin{array}{l}\text { swimming on the } \\
\text { beach }\end{array}$ & 1.145 & 0.766 & \\
\hline \multirow{2}{*}{$\begin{array}{l}3 . \\
4 .\end{array}$} & playing outdoors & 1.824 & 0.610 & \multirow{2}{*}{$\begin{array}{l}\mathrm{H}_{0} \text { accepted } \\
\mathrm{H}_{0} \text { accepted }\end{array}$} \\
\hline & $\begin{array}{l}\text { visiting zoos / } \\
\text { safari parks }\end{array}$ & 2.061 & 0.560 & \\
\hline 5. & $\begin{array}{l}\text { visit the botanical } \\
\text { garden }\end{array}$ & 2.132 & 0.545 & $\mathrm{H}_{0}$ accepted \\
\hline \multirow{2}{*}{$\begin{array}{l}6 . \\
7 .\end{array}$} & visiting agro & 6.379 & 0.095 & \multirow{2}{*}{$\begin{array}{l}\mathrm{H}_{0} \text { accepted } \\
\mathrm{H}_{0} \text { accepted }\end{array}$} \\
\hline & $\begin{array}{l}\text { hot springs } \\
\text { bathing }\end{array}$ & 4.146 & 0.246 & \\
\hline \multirow{2}{*}{$\begin{array}{l}8 . \\
9 .\end{array}$} & Fishing & 5.421 & 0.143 & \multirow{2}{*}{$\begin{array}{l}\mathrm{H}_{0} \text { accepted } \\
\mathrm{H}_{0} \text { accepted }\end{array}$} \\
\hline & $\begin{array}{l}\text { scuba diving and } \\
\text { snorkelling }\end{array}$ & 1.253 & 0.740 & \\
\hline \multirow{2}{*}{$\begin{array}{l}10 . \\
11 .\end{array}$} & Rafting & 12.133 & 0.007 & \multirow{2}{*}{$\begin{array}{l}\mathrm{H}_{0} \text { rejected } \\
\mathrm{H}_{0} \text { accepted }\end{array}$} \\
\hline & $\begin{array}{l}\text { mountain } \\
\text { climbing }\end{array}$ & 0.691 & 0.875 & \\
\hline 12. & Camping & 3.406 & 0.333 & $\mathrm{H}_{0}$ accepted \\
\hline 13. & exploring caves & 1.921 & 0.589 & $\mathrm{H}_{0}$ accepted \\
\hline 14. & $\begin{array}{l}\text { Culture tourism } \\
\text { seeing the } \\
\text { architecture of } \\
\text { buildings }\end{array}$ & 4.110 & 0.250 & $\mathrm{H}_{0}$ accepted \\
\hline 15. & $\begin{array}{l}\text { visiting historical } \\
\text { relics }\end{array}$ & 2.088 & 0.554 & $\mathrm{H}_{0}$ accepted \\
\hline 16. & $\begin{array}{l}\text { watching art } \\
\text { shows }\end{array}$ & 7.596 & 0.055 & $\mathrm{H}_{0}$ accepted \\
\hline 17. & $\begin{array}{l}\text { watching } \\
\text { traditional } \\
\text { ceremonies }\end{array}$ & 2.037 & 0.565 & $\mathrm{H}_{0}$ accepted \\
\hline \multirow{2}{*}{$\begin{array}{l}18 . \\
19 .\end{array}$} & visiting museums & 0.324 & 0.955 & \multirow{2}{*}{$\begin{array}{l}\mathrm{H}_{0} \text { accepted } \\
\mathrm{H}_{0} \text { accepted }\end{array}$} \\
\hline & $\begin{array}{l}\text { seeing economic } \\
\text { activities }\end{array}$ & 0.572 & 0.903 & \\
\hline 20. & $\begin{array}{l}\text { watching cultural } \\
\text { festivals }\end{array}$ & 2.204 & 0.531 & $\mathrm{H}_{0}$ accepted \\
\hline \multirow{3}{*}{$\begin{array}{l}21 . \\
22 . \\
23 .\end{array}$} & $\begin{array}{l}\text { Special tourism } \\
\text { shopping tour }\end{array}$ & 0.236 & 0.972 & \multirow{3}{*}{$\begin{array}{l}\mathrm{H}_{0} \text { accepted } \\
\mathrm{H}_{0} \text { accepted } \\
\mathrm{H}_{0} \text { accepted }\end{array}$} \\
\hline & culinary tour & 1.555 & 0.670 & \\
\hline & $\begin{array}{l}\text { visiting theme } \\
\text { park }\end{array}$ & 0.569 & 0.904 & \\
\hline 24. & $\begin{array}{l}\text { watching sports } \\
\text { competitions }\end{array}$ & 1.525 & 0.676 & $\mathrm{H}_{0}$ accepted \\
\hline
\end{tabular}

\section{DISCUSSION}

\section{Family Travel Motives}

One form of personal escape motive is the drive from within a person to pause from the routine. Each family member has their own routine. These routines take up most of their time. Most of the time the husband and wife workers are spent on work. Most of the time the child is spent on school activities. In fact, for housewives, almost all the time is spent on housekeeping, including the affairs of children and husbands. Family members as individuals have psychological-socio-cultural needs that need to be met. Unfulfilled these needs can cause stress, especially in working wives (Oktaria, Krisnatuti and Muflikhati, 2015). Therefore, they need to temporarily exit from their daily routine. Vacation is the time they can use to vent their needs. One of the activities that families often do to meet this need is tourism activity. This can be proved by phenomena on weekends and other holidays, recreational spots and tourist objects filled with families.

The impulse arises because of an imbalance (disequilibrium) in the psychological-socio-cultural needs of the individual (Crompton, as cited in Shi, Cole and Chancellor, 2012). Instinctively, individuals try to achieve or maintain a balanced state. Therefore, in the event of an imbalance a person needs to pause from his routine. The termination of a routine depends on the continuity of an imbalance experienced, i.e. short or long term. If the imbalance is temporal, then to overcome it enough with the termination of short-term routine, such as staying at home or doing activities other than routine. When the imbalance is protracted, it is necessary to terminate the long term, i.e. need a nice holiday (Crompton, as cited in Shi, Cole and Chancellor, 2012). The family as an institution consisting of individuals also experienced an imbalance condition that prompted him to quit the routine of travelling together.

Another case with interpersonal seeking motives. There are several factors that can cause the emergence of this motive. First, the saturation with routine, alienation from the community and the low social contacts resulting from the work environment resulted in them searching the canals to find a pure "social" world, with family or relatives. One of the canals that can be utilized is family travel. Secondly, as the phenomenon of urban settlement in Indonesia, residential complexes that become the residence of respondents rarely have adequate public space for activities just to release tension / relaxation and to 
interact among the members of its citizens. Situations and conditions such as this leads to family longing to interact in a more relaxed atmosphere and in a wider space. Third, this motive also arises because of changes in values and norms of society that impact on the family. Society considers the quality of family life, both from an economic and non-economic point of view is an important value achieved by the family. To achieve that goal, the family must work and follow certain rules (norms) that apply in the world of work, for example the rules of the world of work that impose working hours so as to spend most of the individual time. With a husband and wife work, the family will be able to achieve the quality of life from an economic angle, but from a non-economic point of view, for example the quality of relationships between family members will be difficult to achieve. Whereas family value is still considered important by the community (Simanjuntak and Sabrina, 2015). This situation requires the family to be creative in order to remain able to achieve these two goals. In the face of this situation, the phenomenon in the community shows that families use leisure to travel.

The interpersonal escape motive comes from poor social interaction. As social beings, humans depend on each other. That's why humans are related. In the context of family, social interaction is more a relationship among family members. The process of social interaction does not always lead to a positive relationship but can be otherwise. The worst social interaction is conflict. Conflict is a social event that includes opposition or disagreement (Lestari, 2012). Conflicts can lead to gaps in social interactions and threats and / or violence among conflicting people. Conflicts within the family can occur between husband and wife, between parent-child, and between sibling (child with child). Conflict can occur because of poor communication in the family (Berlianti et al., 2017).

Conflict has the potential to create an interpersonal escape motive / escapism motive for family members. This escapism is not really a part of social norms within Indonesian households. Although in the family can occur interaction that is not harmonious / conflict

http://ojs.unud.ac.id/index.php/eot between the members (Lestari, 2012), but escapism by way of travel has not been considered in accordance with cultural context. Allegedly this escapism motive is more related to the desire to seek a new social atmosphere, i.e. leaving the community for a while while finding new people who have not been known.

The personal seeking motive refers more to individual, not collective desires. Therefore, it can be understood, that family travel is not to meet the private interests of its members alone, but more to meet the common interests. The family type that ignores individual satisfaction becomes the determinant of why this motive is low. Another reason is that Indonesian society is a high-oriented collective society to maintain the dignity and feelings between people.

Overall, the results of the study concluded that when viewed in the socialpsychological model of travel motivation from Iso-Ahola, the motive of family travel is in the second quadrant, which is the variation of the personal escape and interpersonal seeking motive. In terms of escape motives, families tend to be personal rather than social (interpersonal). That is, family travel because has driven by temporary exit from daily routine, not because want to avoid bad social relationships. On the other hand, in terms of seeking motives, families tend to be social rather than private. That is, they travel not to find something that will meet his personal needs, but want to interact with family members to be more familiar.

The results of this study are similar to other previous studies which show that the meaning of tourism for families is the strengthening of family / relatives and fun / entertainment (Damanik, 2014). In the case of strengthening the family and family ties, the family defines travel and leisure activities as an important necessity because it provides positive psychological and social benefits for its members. In terms of fun and entertainment, family interprets travel activities, psychologically, as a relief (fun). Breaking away temporarily from the daily workload is the essence of tourism, especially if done with family (Damanik, 2014).

The motive mentioned above is different from the individual tourist motif as revealed in Snepenger research, et al. (2006). They examined the travel motivation of 
student aged 18-25 years in the United States. The results showed that both the escape motive and the seeking motive more inclined to the private. So tourists as individuals do travel tend to be driven by motives to meet needs that are personal, not social.

\section{Family Choice Activities}

There are three tourist activities that become a favourite and at the same time, often done by family, namely culinary tours, shopping, and sightseeing. Culinary tourism is the most common activity of the family because of the function of food today that has two dimensions, namely as a means of fulfilment of basic needs and at the same time desire to get the sensation / experience of the food eaten (as a lifestyle). Therefore, in the spare time, many people "hunt" culinary to fulfil the desire. For families, a holiday is a good time to fulfil that desire by doing a culinary tour, exploring the diversity of food created by people of the same or different ethnicity.

The second activity that is favoured by the family is the shopping tour. There are two things that cause it, namely (1) the development of consumer culture and (2) the culture of bringing a souvenir every travelling or a tour. Today's society has become a consumer society. Every day, the shopping centres are filled with people shopping various goods. Every day, mass media advertise a wide range of goods and services. The same thing is also displayed billboards that stand firmly on the street corners. This marketing factor can increase consumer hedonism and impulsive purchases (Satriawan, et al., 2015). Shopping is not just for buying everyday needs, but also for gaining pleasure and satisfaction. Families as part of the community also become consumptive to enjoy this shopping activity. Therefore, the shopping tour preferred most families.

The third favourite activity is sightseeing. This tour activity allows family members to interact and communicate with each other in a relaxed state. These are the moments that they long for because in everyday life they are difficult to make it happen. Every day they have been preoccupied with their respective activities. Father and mother work, while children go to school. They reunite at home in the afternoon or

http://ojs.unud.ac.id/index.php/eot evening when in a tired condition so it is not possible to establish intimacy between them. Their longing for intimacy among family members with a relaxed atmosphere is fulfilled while enjoying the natural scenery together.

The fourth activity most families choose is to visit a theme park. This is understandable because the majority of families in this study had children aged 15-24, who were in the adolescent stage. Adolescence is a turbulent period of storms (Sarwono, 2008). Teens tend to want to experiment or experience new experiences. Today's theme parks offer many games that can boost adrenaline, according to the psyche of adolescents. That is why visiting a theme park is chosen by most families who bring teenage children.

\section{Different Choice of Activities Based on Travel Motives}

All families with different motives do nature tourism. When viewed from the point of at least the energy needed to perform the activity, the activities of nature tourism can be divided into two categories, namely (1) soft activity (i.e. sightseeing, visiting the zoo / safari park, visiting agro, and fishing); And (2) hard activities (i.e. swimming on the beach, outdoor play, diving, white water rafting, mountain climbing, camping, and exploring caves). Fulfilment of the personal escape motive from the routine on the soft activity is more relaxed. Fulfilment of the motive for the hard activity is more to channel the emotion buried through an activity that is difficult to be realized in the routine life. For example, in outdoor play activities, family members can laugh freely and shout without anyone forbid. The escape motive is the drive from within a person to get out of the normal environment, get change from everyday life, and overcome bad mood. This motif can be fulfilled with both types of nature tourism activities.

It seems that the respondents also have considerable interest in cultural tourism activities based on personal escape motives, among others: looking at building architecture, visiting historical relics, watching traditional ceremonies, visiting museums, seeing economic activities, and watching cultural 
festivals. Allegedly this is related to the offer of a relatively different atmosphere with the physical environment of their residence. In fact they live in an uniform residential environment (e.g. house building form, land area, and building area). The family also lives in a society whose activities are mechanistic. This condition makes the family feel bored. The family wants to get out temporarily from normal life, wanting to see something else from his daily life. Saturation to the uniform physical environment can be treated by doing tourism activities related to cultural objects. Boredom against routine activities that are mechanistic can be treated by doing tourism activities related to cultural behaviour.

The result of hypothesis test to see the difference choosing of tourism activity based on tourism motif category concludes that all tourism activities (nature tourism, cultural tourism, and special tourism) are done by families with different motives. All tourist activities, except rafting, are selected by all family types. White-water rafting is a tourist activity most favoured by family escapees. This result is similar to that of Snepenger et al. (2006) which revealed that tourism activities (national parks, recreational parks, sporting events, and beaches) were conducted by travellers with personal escape and high personal seeking motives. His research also revealed that the motive of tourism is not being able to be distinguished by the type of tourists (domestic and foreign).

Thus, it can be concluded that (1) any tourism activity can have two or more different functions (e.g., can as a means of escaping routine and socialization), and (2) any person doing tourism activity can be based on two or more motives . It is, theoretically, proposed by Iso-Ahola that the dichotomy of tourist motives is not exclusive, one can have two tourist motifs simultaneously while doing tourism activities (Snepenger et al., 2006).

\section{CONCLUSION}

There are two dominant motives of family travel, namely the personal escape and interpersonal seeking motive. In terms of escape motives, families tend to be personal rather than social (interpersonal). That is, escape in the context of travel occurs because

http://ojs.unud.ac.id/index.php/eot the family squeezed by a saturate routine, not due to poor social relationships. On the other hand, in terms of seeking motives, families tend to be social rather than private. That is, they travel not to find something that will meet his personal needs, but want to interact with others, in this case with family members to be more familiar.

Families perform various types of natural, cultural, and special tourism activities. They are not the type of special interest tourists. There is no difference in the selection of activities by families with different motives. All tourism activities are favoured by all types of families, both with personal escape, personal seeking, interpersonal escape, and interpersonal seeking. Hypothesis test results show that there is only one activity that is significantly most favoured by family escaping motive, namely rafting.

Based on the results of these studies, it can be noted that there are two important implications. First, the function of family tourism as a temporary escape from the routines to refresh daily activities and as a social search to strengthen the relationship among family members need to be facilitated by the policy of synchronizing holidays for employees with holidays for school children so families get a chance to do a vacation together. Second, families do natural tourism, cultural tourism, and special tourism activities. Therefore, all natural, cultural, and special tourism facilities need to be tailored to the needs of the family, especially regarding its safety and comfort.

\section{REFERENCES}

Amelia, R. and Palupi, S. (2016) 'The Influence of Services Quality to Domestic Tourists' Loyalty through Domestic Tourists' Satisfaction at Mount Bromo Tourism in East Java Indonesia', E-Journal of Tourism, 3(2), pp. $98-104$.

Berlianti, D. et al. (2017) 'Ada apa dengan komunikasi orang tua-remaja?: pengaruhnya terhadap agresivitas remaja pada sesama', Jurnal Ilmu Keluarga \& Konsumen, 9(3), pp. 183194. 
Birenboim, A. et al. (2013) 'Temporal activity patterns of theme park visitors', Tourism Geographies. Taylor \& Francis, 15(4), pp. 601-619.

Bowen, D. and Clarke, J. (2009) Contemporary Tourist Beh... Cabi.

Chen, M. and Pang, X. (2012) 'Leisure motivation: An integrative review', Social Behavior and Personality: an international journal. Scientific Journal Publishers, 40(7), pp. 1075-1081.

Damanik, J. (2013) Pariwisata Indonesia: antara peluang dan tantangan. Pustaka Pelajar.

Damanik, J. (2014) 'Meanings, Purposes, and Activities of Suburban Family Tourism in Yogyakarta, Indonesia', dalam Rethinking Asian Tourism: Culture, Encounters and Local Response, Diedit oleh P. Porananond dan VT King, UK: Cambridge Scholars Publishing, pp. 266-283.

Goeltom, A. D. and Mulyawan, R. (2007) 'Menentukan preferensi dan faktorfaktor yang menyebabkan wisatawan berkunjung ke Kota Bandung sebagai daerah tujuan wisata', Jurnal Pariwisata, 8(4), pp. 44-58.

Hazel, N. (2005) 'Holidays for children and families in need: An exploration of the research and policy context for social tourism in the UK', Children \& Society. Wiley Online Library, 19(3), pp. 225236.

Hsu, C. H. C., Cai, L. A. and Li, M. (2010) 'Expectation, motivation, and attitude: A tourist behavioral model', Journal of travel research. Sage Publications Sage CA: Los Angeles, CA, 49(3), pp. 282296.

Ingkadijaya, R. et al. (2016a) 'Aktivitas Wisata Pilihan Keluarga Perkotaan', Khasanah Ilmu-Jurnal Pariwisata Dan Perhotelan, 7(1).

http://ojs.unud.ac.id/index.php/eot
Ingkadijaya, R. et al. (2016b) 'Tourist activities contribution on family cohesion', Heritage, Culture and Society: Research agenda and best practices in the hospitality and tourism industry. CRC Press, pp. 345-350.

Inskeep, E. (1991) Tourism planning: an integrated and sustainable development approach. Van Nostrand Reinhold.

De Leeuw, E. D., Hox, J. and Dillman, D. (2012) International handbook of survey methodology. Routledge.

Lestari, S. (2012) Psikologi keluarga: Penanaman nilai dan penanganan konflik dalam keluarga. Sri Lestari.

Manulang, S., Bendesa, I. K. G. and Putra, I. N. D. (2015) 'The Effect of Service Quality in International Airport I Gusti Ngurah Rai on Satisfaction, Image, and Tourists Loyalty Who Visited Bali', EJournal of Tourism, 2(1), pp. 9-21.

Nickerson, N. P. and Jurowski, C. (2001) 'The influence of children on vacation travel patterns', Journal of Vacation Marketing. Sage Publications Sage CA: Thousand Oaks, CA, 7(1), pp. 19-30.

Oktaria, R., Krisnatuti, D. and Muflikhati, I. (2015) 'SUMBER STRES, STRATEGI KOPING, DAN TINGKAT STRES PADA BURUH PEREMPUAN BERSTATUS MENIKAH DAN LAJANG', Jurnal Ilmu Keluarga \& Konsumen, 8(3), pp. 133-141.

Recours, R. A., Souville, M. and Griffet, J. (2004) 'Expressed motives for informal and club/association-based sports participation', Journal of Leisure Research. Taylor \& Francis, 36(1), pp. $1-22$.

Shi, L., Cole, S. and Chancellor, H. C. (2012) 'Understanding leisure travel motivations of travelers with acquired mobility impairments', Tourism Management. Elsevier, 33(1), pp. 228231.

e-ISSN: 2407-392X. p-ISSN: 2541-0857 
Shoval, N. et al. (2011) 'Hotel location and tourist activity in cities', Annals of Tourism Research. Elsevier, 38(4), pp. 1594-1612.

Simanjuntak, M. and Sabrina, O. (2015) 'APAKAH KEPRIBADIAN, KEKOSMOPOLITAN, DAN ORIENTASI NILAI MENENTUKAN KUALITAS HIDUP SUBJEKTIF KELUARGA?', Jurnal Ilmu Keluarga \& Konsumen, 8(3), pp. 173-181.

Suardana, I. W., Bendesa, I. K. G. and Antara, M. (2014) 'Satisfaction as Mediators of the Relationship between Motivation and Loyalty of Diving Tourists to Bali', E-Journal of Tourism, 1(1), pp. 12-24.

Sudiarta, I. N. (2015) 'Popularity of tourist attraction in Bali from the perspective of foreign tourists', E-Journal of Tourism, 2(2), pp. 68-73.

Tangeland, T. and Aas, Ø. (2011) 'Household composition and the importance of experience attributes of nature based tourism activity products-A Norwegian case study of outdoor recreationists', Tourism Management. Elsevier, 32(4), pp. 822-832.

Utama, I. G. B. R., Putra, N. D. and Suradnya, I. M. (2014) 'Destination Loyalty Model of Elderly Foreign Tourists Visiting Bali', E-Journal of Tourism, $1(1)$, pp. 50-56.

Walker, G. J., Deng, J. and Dieser, R. B. (2005) 'Culture, self-construal, and leisure theory and practice', Journal of Leisure Research. Taylor \& Francis, 37(1), pp. 77-99. 